\title{
Strategi dalam Membangun Kembali Kemandirian Pengadilan di Indonesia .
}

\author{
Rusli Muhammad
}

\begin{abstract}
The independence of the court has been regarded and it has guarantee in constitution, but in action, especially the action of criminal law enforcement in Indonesia, the independence of the court is in the lowest rank even buried. To rebuild the independence of the court, such that, the correlation of the court with other component is unseparable, for instance, structure, regulation, and personal components of the court. With consideration of the court component, the strategy in rebuilding of the independence of the court is done through taking reconstruction of the court, the reform of regulation and revitalization of the count.
\end{abstract}

\section{Pendahuluan.}

Kemandirian pengadilan menjadi keharusan bagi setiap negara yang mengklaim dirinya sebagai negara hukum karena pada negara yang demikian itulah mampu mengantarkan negara itu melaksanakan hukum secara konsekuen. Pengalaman telah membuktikan, bahẉa, jika mengabaikan kemandirian pengadilan maka proses penegakan hukum yang berintikan keadilan akan macet dan kalau masih terlihat berjalan, maka dasar kepentingannya bukan untuk keadilan melainkan demi kepentingan tertentu.

Kemandirian pengadilan secara teoritik dan konsepsional dalam berbagai literatur, sebenarnya telah diakui dan telah banyak dibicarakan. Namun di dalam kenyataannya baik di dalam peraturan perundang-undangan dan terutama dalam praktek penegakan hukum pidana di Indonesia, kemandirian pengadilan tersebut tidak sebaik dengan apa yang tertulis itu. Sebaliknya, kemandirian pengadilan adalah sangat lemah, bahkan sangat buruk. Lembaga ini bukan lagi sebagai lembaga independen tapi telah menjadi lembaga dependen yang hanya memihak dan melayani kepentingan-kepentingan golongan penguasa dan pengusaha.

Tingkat kemandirian pengadilan seperti itu sungguh memprihatinkan, mengingat peran-peran yang diembannya adalah sungguh mulia yang menempatkannya sebagai lembaga 
yang terhormat. Apakah tingkat kemandirian pengadilan yang demikian masih dapat diperbaiki,. dikembalikan sebagaimana diisyaratkan oleh konstitusi? Banyak orang yang merasa pesimis akan hal itu, karena bagi mereka kemandirian memang sulit untuk diwujudkan apalagi dengan kondisi seperti sekarang, di mana budaya korup masih bagian dari kehidupan nyata dan sistem rekruitmen serta dominasi kekuasaan eksekutif belum berubah. Namun demikian apakah sikap pesimistik ini tetap dibiarkan dan tetap membiarkan kondisi kemandirian pengadilan tetap terpuruk seperti itu? Tentunya tidak! Oleh karena itu upaya untuk memperbaiki dan membangun kembali kemandirian pengadilan tetap harus diperjuangkan. Persoalannya adalah strategi bagaimana yang dapat dilakukan dalam membangun kembali kemandirian pengadilan itu? Persoalan inilah yang akan disoroti dalam tulisan ini.

Untuk menentukan strategi di dalam membangun kembali kemandirian pengadilan, kiranya perlu memperhatikan berbagai teori yang dapat menjadi dasar pijakan di dalam menentukan dan memilih langkah-langkah yang strategis itu, dan untuk kebutuhan ini beberapa teori cukup relevan untuk dapat digunakan.

Pada kajian sosiologis memperihatkan adanya kekuatan-kekuatan yang berpengaruh yang saling berhubungan secara timbal balik di dalam melakukan sebuah perekayasaan masyarakat. Oleh karena itu menarik apa yang dikatakan oleh Seidmen yang menggambarkan adanya tiga kekuatan pengaruh yang secara timbal balik saling berhubungan dalam kaitannya dengan Social engineering. Ketiga kekuatan tersebut adalah:' ${ }^{1}$ Pertama, pembentuk undang-undang. Kedua, pemegang peranan (warga negara) dan ketiga adalah pelaksana. Ketiga kekuatan, inilah yang secara bersama-sama dan seimbang perlu mendapat perhatian, artinya tidak akan mungkin sebuah undang-undang yang dihasilkan oleh pembentuk undangundang berjalan dengan efektif tanpa memperhatikan pemegang peran dan pelaksananya, demikian pula sebaliknya. Oleh karena itu pemahaman yang menyeluruh kepada masing-masing kekuatan itu harus mendapat perhatian sewajarnya, termasuk juga di dalam menentukan strategi pembangunan: kembali kemandirian pengadilan.

Selain ajaran tersebut di atas, ajaran Friedman tentang sistem hukum (legal system) perlu pula mendapat perhatian. Menurut Lawrence M. Friedman mengatakan bahwa, sistem hukum terdiri dari 3 (tiga) komponen, yakni Structure, Substance dan legal Culture. ${ }^{2}$ Komponen struktur yang dimaksud adalah bentuk yang permanen, badan institusi yang bekerja mengikuti proses-proses dalam batasan-batasannya. Substansi adalah normanorma atau aturan-aturan aktual yang digunakan oleh institusi yang menentukan cara-cara menggambarkan suatu perilaku

'Robert B. Seidman, dalam Satijipto Rahardjo, Hukum dan Perubahan Sosial (Bandung: Penerbit Alumni, 1983), him. 161.

2 Lawrence M. Friedman, The Legal System, A Social Science Perspective (New York: Russell Sage Foundation, 1975), hlm. 14-15. Lihat juga dalam bukuniya yang lain yakni, Law and Society An Introduction (United States of America: Prentice-Hall, inc. Rnglewood Cliffs, N.J. 07632, 1977), h/m. 6-9. 
dan menentukan kemungkinan ke arah mana bertindak. Sementara budaya hukum adalah elemen sikap dan nilai sosial yang diwujudkan di dalam tingkah laku konkrit masyarakat.

Berdasarkan ajaran-ajaran tersebut di atas, maka ruang lingkup strategi yang akan digunakan berkisar pada kekuatan-kekuatan yang berpengaruh dan terutama pada komponen-komponen sistem hukum itu. Artinya komponen-komponen sistem hukum tersebut akan menjadi titik perhatian sekaligus sebagai batasan di dalam menentukan strategi membangun kembali kemandirian pengadilan. Ini dilakukan karena komponen itu sekalipun memiliki fungsi yang berbeda namun ketiganya memiliki pengaruh yang kuat di dalam sebuah perekayasaan sosial menuju suatu cita-cita yang mulia, termasuk di antaranya adalah "kemandirian pengadilan". Dengan batasan yang demikian maka strategi yang dapat dilakukan adalah restrukturisasi pengadilan, reformasi terhadap peraturan perundang-undangan dan revitalisasi pengadilan. Untuk lebih jelasnya masingmasing strategi ini akan diuraikan berikut ini.

\section{Restrukturisasi Pengadilan}

Gagasan untuk melakukan restrukturisasi pengadilan tidak terlepas dari keadaan struktural yang ada di pengadilan. Persoalanpersoalan struktural yang sangat krusial selama ini adalah dominannya kekuasaan eksekutif terhadap lembaga (badan) peradilan yang notabene sebagai lembaga pemegang dan pelaksanaan kekuasaan kehakiman. Keterlibatan kekuasaan eksekutif yang dirasakan sangat mengganggu adalah pada urusan organisasi, administrasi dan finansial. Pada bidang ini, pengadilan tidak memiliki kewenangan membinanya dan mengontrónya, melainkan berada pada lembaga eksekutif yakni pada Departemen yang membawahinya. ${ }^{3}$ Restrukturisasi terhadap persoalan ini sebenarnya telah dilakukan melalui amandemen UUD 1945 dan dengan dikeluarkannya undang-udnang baru tentang Kekuasan Kehakiman yakni UU Nomor 4 Tahun 2004. Namun realisasinya hingga saat ini belum juga dilaksanakan.

Persoalan struktural lain yang cukup menarik adalah menyangkut rekruitmen hakim. Rekruitmen hakim pada semua tingkatan pengadilan baik hakim Pengadilan Negeri, hakim Pengadilan Tinggi maupun hakim Mahkamah Agung, termasuk penentuan ketua Mahkamah Agung, terutama berkaitan dengan prosedur dan kelembagaannya adalah menjadi urusan dan didominasi oleh kekuasaan eksekutif.

Dominasi kekuasaan eksekutif ini sedikit agak berkurang pada zaman reformasi ditandai dengan ikut andilnya peran lembaga legislatif di dalam menentukan calon Hakim Agung termasuk di dalam hal pemilihan ketua Mahkamah Agung. Barangkali diharapkan

${ }^{3}$ Departemen yang dimaksudkan melakukan pembinaan dan kontrol di bidang organisasi, administrasi dan finansial adalah Departemen kehakiman untuk Peradilan Umum, Departemen Hankam untuk Peradilan Militer dan Departemen Agama untuk Peradilan Agama. Secara juridis kondisi ini telah berubah dengan dikeluarkannya UU No. 35 Tahun 1999 yang kemudian dicabut oleh UU No. 4 Tahun 2004, namun secara de facto pembinaan dan kontrol seperti itu hingga sekarang masih berlangsung. 
dengan adanya fit and proper test dari DPR, persoalannya dapat berkurang, namun justru sebaliknya persoalannya semakin berkembang sebab semakin bertambahnya kekuasaan yang: mencampuri kekuasaan yudikatif.

Tidak kalah menariknya dengan rekruitmen hakim, jaminan kekebalan dan kesejahteraan komponen peradilan khususnya hakim adalah juga persoalan struktural yang sangat memprihatinkan. Selama ini kekebalan hakim adalah sangat rapuh karena belum adanya jaminan undang-undang yang memberi perlindungan terhadap persoalan tersebut. Tidak adanya perlindungan tersebut dapat menimbulkan keraguan dan kekhawatiran pada setiap individu hakim di dalam melaksanakan tugasnya. Oleh karena itu adalah sangat wajar jika 'di dalam menghadapi perkara yang penuh dengan risiko baik pada keselamatan badan dan nyawa, maupun pada profesinya selaku hakim, akan lebih memilih mencari selamat ketimbang memutuskan sesuai dengan hati nuraninya ataupun tuntutan keadilan hukum.

Tak kálah pentingnya pula adalah masalah kesejahtèraan hakim. Masalah ini sangat memprihatinkan, gaji dan tunjangan sosial masih jauh lebih rendah bila dibandingkan dengan gaji atau tunjangan wakil-wakil rakyat di DPR, belum lagi bila dibandingkan dengan manajer atau direktur suatu perusahiaan baik milik negara maupun milik swasta. Cobalah bandingkan dengan gaji seorang direktur bank milik negara atau milik swasta, sungguh luar biasa jauhnya bagaikan bumi dengan langit. Bagaimana para hakim akan sanggup menahan berbagai godaan ketika ia harus bekerja dengan tanggungan sekian keluarga, sementara gajinya hanya sekedar cukup menyambung hidup .
Rendahnya gaji para hakim akan sulit membentengi dirinya bila mana berbagai rayuan yang bertubi-tubi dari pihak-pihak yang berperkara yang amat mungkin menawarkan uang jasa dengan jumlah beratus kali lebih besar dari gaji resmi yang diterimanya tiap bulan. Sudah sekian banyak fakta yang ditemukan di mana benteng pertahanan hakim telah diruntuhkan oleh pendapatan kotor yang illegal dari pihak-pihak yang juga tidak bertanggung jawab. Sekiranya benteng pertahanan para hakim masih didukung oleh moral atau akhlak yang mulia, barangkali berbagai rayuan dan bujukan iblis berwujud manusia itu, tetap dapat dipertahankan sekali pun gaji hanya pas-pasan untuk hidup. Sayangnya hakim yang berakhlak mulia itu sekarang ini, jumlahnya sangat sedikit.

Persoalan kewenangan melakukan Hak Uji Materiil (Judicial Review) terhadap semua peraturan perundang-undangan adalah juga persoalan struktural yang perlu pula mendapat perhatian. Selama ini lembaga pengadilan (Mahkamah Agung) hanya berhak menguji peraturan perundang-undangan di bawah undang-undang. Jika menyangkut Undangundang Mahkamah Agung tidak memiliki kewenangan untuk itu, sementara persoalan yang muncul di sekitar undang-undang adalah cukup banyak.

Sederetan persoalan-persoalan struktural tersebut di atas dapat saja menjadi penyebab melemahnya kemandiriari pengadilan dan bila tetap dibiarkan tidak saja melemahkan kemandirian pengadilan namun akan merembet pula pada proses penegakan hukum. Oleh karena itu, dengan langkah restrukturisasi diharapkan dapat menghasilkan bentuk-bentuk struktur baru yang mendukung terbentuknya kemandirian pengadilan. 


\section{Reformasi Peraturan Perundang- undangan}

Salah satu langkah starategi yang dapat dilakukan dalam membangun kembali kemandirian pengadilan adalah dengan melakukan reformasi terhadap berbagai peraturan perundang-undangan khsusnya peraturan-peraturan yang berkaitan dengan kekuasaan kehakiman yang secàra tegas ataupun secara samar-samar membatasi kemandirian pengadilan.

Adalah wajar jika Pada Era Reformasi ini kita akan kembali mengoreksi kehidupan peraturan perundang-undangan yang ada, yang berarti bahwa selain bidang lainnya, bidang hukum adalah satu hal yang amat mendesak segera direformasi. Hal ini dilatarbelakangi oleh adanya pandangan kuat bahwa produk perundang-undangan yang dibuat oleh rezim Orba lebih berfungsi memberikan keabsahan formal terhadap usaha mempertahankan atau memperbesar kekuasaan dan tujuan-tujuan subyektif pemegang kekuasaan dari pada sebagai sarana mencerdaskan kehidupan bangsa, sarana menyelesaikan konflik demi mencapai keadilan ataupun sebagai sarana menselaraskan berbagai hak-hak guna meningkatkan kesejahteraan rakyat.

Pada kenyataannya pengadilan dalam proses peradilan pidana lebih cenderung tampak sebagailembaga dependen (tergantung) daripada menjadi lembaga independen (mandiri) bagi upaya pendayagunaan hukum ke arah terwujudnya kebenaran dan keadilan. Kecenderungan ini disebabkan berbagai peraturan hukum yang ada baik yang dihasilkan di jaman ORLA maupun di jaman ORBA membatasi kebebasan atau kemandirian pengadilan itu. Kewenangan atau kekuasaan yang diberikan oleh undangundang kepada lembaga perádilan (yudikatif) tidak memperlihatkan kesamaan dan keseimbangan dengan kekuasaan eksekutif maupun legislatif, sehingga hukum menjadi tidak berfungsi dalam mengintegrasikan kepentingan yang menjadi syarat kemandirian pengadilan.

Reformasi terhadap peraturan perundangundangan semestinya dimaknai sebagai perubahan ke arah perbaikan dalam batasbatas aturan main yang telah disepakati bersama. Dalam perspektif konstitusionalisme, aturan main tersebut menurut Aminoto ${ }^{4}$ sebagaimana disebutkan di bahwa, akan memuat gambaran mengenai struktur kekuasaan, bagaimana kekuasaan diatur dan dibagi-bagi, apa fungsi lembaga-lembaga tertentu, apa saja hak dan kewajiban warga negara, bagaimana aturan permainan politik yang seharusnya berlaku, dan sebagainya.

Pendek kata, aturan yang dibuat berdasarkan kesepakatan ini akan menjamin adanya keseimbangan antara hak dan kewajiban yang memerintah di satu pihak, dengan hak dan kewajiban yang diperintah di pihak lain. Pada realitasnya di beberapa peratuarn perundang-undangan, khususnya di bidang kekuasaan kehakiman, keseimbangan tersebut sama sekali tidak tampak. Oleh karena itu wajar jika kemudian timbul keinginan untuk melakukan reformasi terhadap peraturan perundang-undangan itu.

${ }^{4}$ Harian Kedaulatan Rakyat, tanggal 24 Juni 1998 
Reformasi terhadap perundangundangan tidak terbatas pada peraturan organik melainkan harus menjangkau pada konstitusi (UUD) dan harus menjadi pilihan pertama dalam melakukan reformasi itu. Pemilihan UUD sebagai sasaran pertama reformasi karena mengingat status dan posisi UUD sangat vital dalam sistem hukum Indonesia. Namun tidak menutup kemungkinan terjadinya berbagai permasalahan yang tidak menyenangkan dalam dunia hukum (peradilan) serta terjadinya ketimpanganketimpangan dalam ketatanegaraan kita selama ini, terutama hilangnya kebebasan kekuasaan kehakiman dalam upaya penegakan hukum tidak semata-mata bersumber dari pelaku-pelaku dari para penyelenggara negara atau para penegak hukum tetapikemungkinan besarjustru berasal dari ketidakberesan UUD 1945 itu sendiri.

Berbagai hal yang mendorong dilakukannya reformasi terhadap UUD. Di antaranya adalah, kekuasaan kehakiman yang diharapkan sebagai pengimbang terhadap kekuasaan lainnya, sungguh disayangkan ternyata rumusan-rumusan pasal UUD 1945 yang berisi jaminan kemerdekaan kekuasaan kehakiman itu singkat dan paling sedikit dibandingkan dengan kekuasan lain. Hal ini memang menjadi salah satu ciri perumusan pasal-pasal UUD 1945, yang disatu pihak merupakan kekuatan, namun dipihak lain mungkin pula menjadi kelemahan. ${ }^{5}$ Dengan rumusan-rumusan yang singkat dan sangat timpang itu maka membuka peluang kepada kekuasaan lain (eksekutif) mudah menginterpensi ke dalam kekuasaan yudikatif sehingga kekuasaan kehakiman terdesak dan kemudian menjadi lembaga marginal.

Jika mencermati lebih dalam, ternyata tidak sekedar timpangnya pengaturan kekuasan kehakiman di dalam UUD melainkan telah terjadi pula reduksi terhadap konsep kekuasaan kehakiman. Konsep kekuasan kehakiman di dalam UUD sekalipun telah dilakukan amandemen ternyata konsepnya masih seperti yang tercantum di dalam UU No 14 Tahun 1970, yakni kekuasaan kehakiman hanya dilaksanakan oleh Mahkamah Agung dan badan peradilari lainnya (Pengadilan Negeri dan Pengadilan Tinggi). Konsep ini menempatkan kekuasaan kehakiman terbatas sebagai kekuasaan mengadili yang dilakukan oleh Mahkamah Agung dan badan peradilan lainnya. Bagaimana dengan kekuasaan lainnya seperti kekuasaan penyelidikan/penyidikan yang dilakukan oleh Kepolisian, kekuasaan penuntutan yang dilakukan oleh Kejaksaan? Apakah ini tidak termasuk kekuasaan kehakiman? Tentunya jika dikaitkan dengan sistem peradilan pidana terpadu, maka masing-masing kekuasaan tersebut adalah juga menjadi bagian kekuasaan kehakiman. ${ }^{6}$ Namun tidak demikian rumusan Pasal 24 UUD '45 Amendemen ke III. Oleh karena itu perlu peninjauan kembali, jika perlu kembali lagi

${ }^{5}$ Yusril Ihza Mahendra, "Adakah Kemerdekaan Kekuasaan Kehakiman", Makalah dalam seminar Kekuasaan. Kehakiman dan Sistem Peradilan Dilndonesia pada Fakultas Hukum UNDIP, Semarang 1996, hlm. 3

"Istilah "kekuasasn kehakiman" (di bidang hukum pidana)) menurut Barda Nawawi Arief identik dengan kekuasaan/kewenangan menegakkan hukum dan keadilan yang diimplementasikan dalam 4 (empat) sub-sistem, yaitu: (1) kekuasaan 'penyidikan" (oleh badan/lembaga penyidik); (2) kekuasaan "penuntutan" (oleh badan/ lembaga penuntut umum); (3) kekuasaan "mengadili dan menjatuhkan putusan/pidana" (oleh badan pengadilan); 
kepada perumusan seperti sebelum amandemen di mana kekuasaan kehakiman tidak terbatas dijalankan oleh badan-badan peradilan melainkan oleh badan-badan kehakiman.

Persoalan lain di sekitar UUD hasil perubahan ketiga, dimunculkan pula lembaga baru yakni Komisi Yudisial dan Mahkamah Konstitusi. Komisi Yudisial tidak ada masaiah, namun untuk Mahkamah Konstitusi, perlu kejelasan lebih lanjut, sebab di dalam. perubahan ketiga UUD tersebut; sebagaimana tersebut di dalam Pasal 24, menempatkan Mahkamah Konstitusi terpisah dengan Mahkamah Agung dan memberikan kedudukan yang sama yakni keduanya dijadikan sebagai pelaksana dari kekuasaan kehakiman.

Persoalannya adalah siapa di antara kedua Mahkamah tersebut yang dijadikan sebagai pucuk pengendali dari kekuasaan kehakiman; apakah keduanya diberi. kewenangan untuk itu, sehingga keduaduanya diberi kewenangan untuk menentukan dan memutus atas semua persoalan hukum yang terjadi? Rasanya tidak mungkin dilakukan, karena adanya dua pucuk pimpinan dalam suatu kekuasaan ketatanegaraan adalah sesuatu yang tidak lazim: Bukankah kekuasaan eksekutif hanya dipimpin oleh seorang presiden? Demikian pula kekuasaan legislatif hanya dipimpin oleh seorang ketua? Dengan demikian tidak akan mungkin kedua mahkamah tersebut menjadi pengendali di dalam-melaksanakan kekuasaan kehakiman.

Tidak adanya kekuasaan pengendali tersebut akan berakibat terjadinya kesulitan di dalam menyelesaikan persoalan hukum yang timbul-di dalam masing-masing mahkamah jika sekiranya masing-masing mahkamah tersebut sulit menyelesaikannya sendiri. Mahkamah mana lagi yang diharapkan dapat menyelesaikannya? Sementara keduanya tidak ada yang diberi kewenangan untuk itu. Namun jika keduanya diberi kewenangan berarti ,akan terjadi kembali dualisme kekuasaan versi baru di dalam kekuasaan yudikatif, yakni di tangan Mahkamah Konstitusi. dan Mahkamah Agung.

- Dengan adanya persoalan tersebut, barangkali kedudukan Mahkamah Konstitusi perlu.dipikir dan ditimbang ulang, apakah tetap dipisahkan dengan Mahkamah Agung ataukah menjadi: bagian dari Mahkamah Agung sehingga fungsi-fungsi yang semula ditawarkan kepada Mahkamah Konstitusi adalah juga menjadi fungsi Mahkamah Agung yang dijalankan oleh Mahkamah Konstitusi. Dengan posisi tersebut menjadikan Mahkamah Agung sebagai Pengadilan Negara Tertinggi sekaligus sebagai Mahkamah Konstitusi.

Dengan mengikuti pemikiran di atas, maka perubahan ketiga UUD yang memberi kewenangan Mahkamah Agung dalam hal Hak Uji Materiil, hanya terbatas pada peraturan perundang-undangan di bawah undang-undang menjadi tidak relevan dan

dan (4) kekuasaan "pelaksanaan putusan/pidana" (oleh badan/aparat pelaksana/eksekusi). Dengan demikian "kekuasaan kehakiman (di bidang hukum pidana)" dilaksanakan oleh empat badan/lembaga tersebut dan keempat badan itulah dapat disebut sebagai "badan-badan kehakimaan". Lihat Barda Nawawi Arief, "Sistem Peradilan Pidana Terpadu dalam Kaitannya dengan Pembaharuan Kejaksaan", disajikan pada forum Dengar Pendapat Publik, Pembaruan Kejaksaan", Jakarta 24-25.Juni 2003, him 1-4. 
sebaliknya pertu perubahan kembali dengan mengikuti pikiran-pikiran yang berkembang di masyarakat baik melalui berbagai seminar atau loka karya, bahwa Hak Uji Materiil ini adalah menjadi kewenangan mutlak Mahkamah Agung terhadap semua bentuk peraturan perundang-undangan.

Setelah UUD sebagai agenda pertama reformasi, pilihan reformasi di bidang peraturan perundang-undangan berikutnya adalah reformasi terhadap Undang-Undang Nomor 4 Tahun 2004 tentang Kekuașaan Kehakiman. Undang-undang ini di buat dalam rangka penyesuaian terhadap amandemen UUD khususnya mengenai kekuasaan kehakiman, sekaligus menyatakan UndangUndang Nomor 14 Tahun 1970 tentang Ketentuan-ketentuan Pokok Kekuasaan Kehakiman sebagaimana telah diubah dengan Undang-Undang Nomor 35 Tahun 1999 tentang Perubahan Atas Kekuasaan Kehakiman dinyatakan tidak berlaku.

Sekalipun undang-undang ini telah banyak melakukan perubahan terhadap materi undang-undang sebelumnya, namun tidak berarti undang-undang ini telah menutup dilakukannya reformasi. Undang-undang Nomor 4 Tahun 2004 ternyata masih meninggalkan pesoalan sehingga masih perlu dilakukan reformsi lebih lanjut. Persoalanpersoalan yang tersisa dari undang-undang ini adalah lagi-lagi kekuasaan kehakiman mengalami pembatasan, yakni terbatas pada kekuasaan mengadili yang dilakukan oleh Mahkamah Agung dan badan peradilan yang berada di bawahnya dalam berbagai lingkungan peradilan. Ketentuan ini tidak berbeda dengan rumusan UUD hasil amandemen yang membatasi kekuasaan kehakiman terbatas pada kekuasaan mengadili di luar kekuasaan penyidikan dan penuntutan.

Undang-Undang Nomor 4 Tahun 2004 ini kembali mempertegas ketentuan UndangUndang Dasar tentang kedudukan Mahkamah Konstitusi dan kewenagan melakukan Hak Uji Materiil undang-undang terhadap UndangUndang Dasar. Ini berarti persoalannya adalah sama halnya dengan apa yang telah disinggung tersebut di atas yang berarti menghendaki pula undang-undang ini di reformasi.

Jika Undang-Undang Nomor 4 Tahun 2004 memuat hal-hal baru (namun menimbulkan perdebatan), ternyata terdapat persoalan prinsip terabaikan oleh undangundang ini, yakni tidak adanya ketentuan tentang jaminan profesi berupa immunitas atau perlindungan bagi para hakim ketika menjalankan profesinya. Tidak adanya jaminan seperti itu akan menimbulkan kekhawatiran bahkan ketakutan bagi para hakim karena mungkin saja sewaktu-waktu dalam menjalankan atau setelah selesai menjalankan profesinya mereka dapat dituntut atau dicopot dari jabatannya.

Mestinya, undang-undang ini memperhatikan hal tersebut karena jaminan profesi telah mendapat perhatian internasional dan menjadi bagian dari prinsip-prinsip dasar kemandirian pengadilan seperti yang telah diputuskan dalam Kongres PBB di. Itali pada tahun 1985 yang menentukan jaminan rahasia dan kekebalan profesi adalah salah satu prinsip dasar kemandirian pengadilan. ${ }^{7} \mathrm{Hal}$

7 Lihat Sevent United Nations Congress on The Prevention of Crime And The Treatment of Offenders Milan, 26 August-6 September 1985, (New York: Unted Nations Publications, 1986), hlm. 59-62. 
yang sama juga telah mendapat perhatian dari International Bar Association (IBA), terlihat dari berbagai konferensi yang telah dilakukan berhasil merumuskan standar minimal tentang "kemandirian peradilan". Pada Konferensi Blennial ke-19 yang diselenggarakan tanggal 22 Oktober 1982 di New Delhi India telah disetujui ketentuan tentang standar minimal dari kemandirian pengadilan, di antaranya adanya kemandirian personal dan kemandirian substansial. ${ }^{8}$ Keseluruhan persoalan-persoalan seperti itulah mendorong dilakukan reformasi terhadap UndangUndang Nomor 4 Tahun 2004 sekalipun usianya masih sangat muda.

Selain kedua hal tersebut di atas, peraturan perundang-undangan lainnya yang perlu mendapat reformasi adalah UndangUndang Nomor 2 Tahun 1986. Undangundang ini sudah tidak relevan lagi karena ia merupakan pelaksanaan ketentuan-ketentuan dan asas-asas yang tercantum di dalam Undang-undang Nomor 14 Tahun 1970 yang telah mengalami perubahan melalui UndangUndang Nomor 35 Tahun 1999, sementara kedua undang-undang tersebut telah dicabut dengan Undang-Undang Nomor 4 Tahun 2004. Oleh karena itu ke depan perlu segera menyusun Undang-Undang Tentang
Peradilan Umum menggantikan UndangUndang Nomor 2 Tahun 1986 tersebut di atas.

\section{Revitalisasi Pengadilan}

Revitalisasi pengadilan dimaksudkan sebagai suatu usaha untuk mengembalikan pengadilan menjadi lembaga yang bermakna, lembaga yang kembali kepada fungsi yang sesungguhnya dan lembaga yang penting bagi kehidupan masyarakat. Revitalisasi sendiri mengandung pengertian mengembalikan agar lembaga peradilan hidup dan berfungsi kembali. ${ }^{9}$

Revitalisasi pengadilan tidak lepas dari adanya peranan terhormat dan strategis yang dimiliki, namun peranan dan kedudukan lembaga pengadilan yang terhormat itu, rasanya kian hari kian terkikis oleh perilakuperilaku yang ditampilkannya dan kini semakin banyak yang tidak respek bahkan dengan suatu keprihatinan memberikan kritikan-kritikan tajam atas penampilan dan gaya yang ditampilkan.

Sesungguhnya peranan pengadilan jika dikelompokkan, ada peran yuridis formal dan peran yuridis materiil. ${ }^{10}$ UndangUndang Dasar membuka peluang untuk kedua peranan ini sebab lembaga peradilan dalam

\footnotetext{
${ }^{8}$ Ketentuan mengenai standard minimum tentang kemandirian pengadilan dari IBA tersebut dapat dibaca di dalam Shimon Shetreet dan Jules Deschenes, ed. Judicial Independence The Conttemporary Debate (Netherlands: Martinus Nijhoff Publishers, 1985), hlm. 388-392.

'Sudikno Mertokusumo, "Revitalisasi dan Fungsionalisasi Lembaga Peradilan ", Makalah pada Diskusi Usulan Rancangan GBHN '98, Fakultas Hukum UII Yogyakarta, 15 Juli 1987, hlm. 2.

${ }^{10}$ Peran yang bersifat yuridis formal dimaksud adalah peran yang dijalankan oleh Lembaga peradilan berdasarkan ketentuan undang-undang, yaitu melaksanakan peraturan perundang-undangan melalui kegiatan berupa menerima, memeriksa, mengadili dan menjatuhkan putusan. Sedangkan peran yang bersifat yuridis materiil adalah peran yang dijalankan oleh lembaga peradilan berdasarkan hati nurani, diskresi dan kondisikondisi sosial politik tertentu melalui berbagai bentuk kegiatan ke arah tegaknya hukum, keadilan, dan perlindungan
} 
tatapan konstitusi merupakan lembaga sentral yang tidak saja bertanggungjawab dalam upaya penegakan hukum, melainkan pula bertanggungjawab di dalam melindungi, mendamaikan, mencerdaskan dan meningkatkan kesejahteraan rakyat.

Dengan demikian, jika lembaga Pengadilan ditempatkan pada dataran konstitusi dan ideologi Pancasila maka peranan pengadilan tidak sekedar melaksanakan tugas yuridis dengan berkotak katik dalam penerapan aturan-aturan hukum formal dalam memutus perkara yang dihadapinya, melainkan pula harus mengambil peran lain yakni peran yang bersifat juridis materiil. Dengan peranan yang demikian berarti pengadilan harus juga berpolitik dan pejuang ideologi. Satjipto Rahardjo mengatakan bahwa Peran politik ini meliputi keterlibatan MA untuk secara sadar membawa perahu negara ini menuju kepada tujuan seperti tercantum dalam konstitusi."

Sebagai implementasi dari peran politik, lembaga pengadilan (dalam semua tingkatannya; PN, PT dan MA) selain berfikir politis juga harus terlibat dalam kegiatankegiatan yang bersifat politis terutama bila kegiatan itu menyangkut kebijaksanaan di bidang hukum. Hal demikian pengadilan senantiasa melihat dan menguji setiap produk hukum dengan menggunakan ukuran-ukuran konstitusi. Lewat putusannya akan menentukan apakah suatu produk hukum sesuai atau tidak dengan konstitusi yang ada. Ketika ada atuaran-aturan hukum yang diskriminatif ataupun kebijakan-kebijakan politik yang dapat menghambat kesejahteraan masyarakat, Lembaga Pengadilan harus berani menyampingkan atau membatalkan aturan hukum yang demikian dengan lebih mengutamakan kesejahteraan masyarakat. Dengan cara demikian berarti pengadilan telah membawa negara ini kepada tujuan yang dikehendaki oleh konstitusi, yakni melindungi segenap bangsa dan memajukan kesejahteraan umum.

Dalam hal ini, perlu pula mengingat dan untuk diperhatikan kembali tentang peranan atau tugas pengadilan (hakim ) sebagaimana yang dijelaskan di dalam bagian penjelasan Undang-Undang Darurat No 1 Tahun 1951. Dalam penjelasan tersebut disebutkan: ${ }^{12}$

Dalam "suatu Negara Hukum yang demokratis dan berbentuk kesatuan", dalam

terhadap harkat dan martabat manusia, ketertiban, ketentraman, keamanan dan kesejahteraan masyarakat sebagaimana yang telah diamanatkan oleh konstitusi 1945 . Istilah yuridis materiil ini, dilihami oleh istilah "Penegakan kondisi sosial politik tertentu melalui berbagai bentuk kegiatan ke arah tegaknya hukum, keadilan, dan perlindungan terhadap harkat dan martabat manusia, ketertiban, ketentraman, keamanan dan kesejahteraan masyarakat sebagaimana yang telah diamanatkan oleh konstitusi 1945 . Istilah yuridis materi]l ini, diilhami oleh istilah "Penegakan Hukum Secara Materiil" yang dikemukakan oleh Barda Nawawi Arief dalam bukunya Beberapa Aspek Kebijakan Penegakan dan Pengembangan Hukum Pidana (Bandung: Citra Aditya Bakti, 1998), hlm. 7.

${ }^{11}$ Op.cit. hlm. 2.

${ }_{12}$ Kuntoro Basuki dan Retnosupartinah, Kumpulan Undang-Undang dan Peraturan-Peraturan Pemerintah Yang Berhubungan dengan Masalah Peradilan" (Yogyakarta: Seksi Peradilan Fakultas Hukum UGM, 1980) him. 98-99. 
hal ini. Negara Republik Indonesia (Pàsal 1 Undang-undang Dasar Sementara), Rakyat yang memegang Kedaulatan harus percaya, bahwa dalam Negaranya terdapatlah suatu alat Negara-hukum' itu yang tak berpihak (artinya yang tidak tunduk begitu saja pada alat perlengkapan Negara yang lain) dan yang memenuhi:

"semata-mata pada syarat kepandaian, kecakapan dan'kekuatan tak-tercela yang ditetapkan'dengan Undang-undang'(Pasal 101 ayat 2. Undang Undang Dasar), dan "bertentangan dengan kemauannya tidak seorang juapun dapat dipisahkan" dari padanya (Pasal 13 ayat 2 Undang Undang Dasar), untuk memberi "bantuan'-hukum yang sungguh" kepada "sekalian orang yang ada di daerah Negara" yang "sama berhak menuntut perlindungan untuk diri dan harta bendanya", menuntut perlakuan dan perlindungan yang sama terhadap tiap-tiap pembelakangnya dan 'terhadap tiap-tiap penghasutan untuk melakukan pembelakangan demikian", melawan perbuatan-perbuatan yang berlawanan dengan hak-hak dasar yang diperkenankan kepadanya menurut hukum", dalam persamaan yang sepenuhnya mendapat perlakuan jujur dalam perkaranya dalam hal menetapkan hak-hak dan kewajibankewajibannya dan dalam hal menetapkan apakah suatu tuntutan hukuman yang terhadapnya beralasan atau tidak" dst...

Pada bagian lain dari penjelasan Undang-Undang Dárurat tersebut disebutkan bahwa Tugas hakim itu amat berat. Tugas itu menuntut pëlajaran ilmu hukum yang sempurna dan yang tiada berkeputusan, dan melainkan kepandaian dan kecakapan istimewa itu, peri-peri perangai dan peri-peri budi yang agak berlainan daripada yang harus dipenuhi oleh seorang pegawai Pamóngpraja, seorang pegawai tata-usaha atau seorang pegawai Polisi. ${ }^{13}$

Demikianlah berbagai peranan yang seharusnya diemban oleh pengadilan. Idealnya memang demikian, pengadilan seharusnya mempunyai multi peran atau multifungsii: Namun demikian, peranan yang tergambarkan di atas hanyalah sebuah harapan dan cita-cita yang terumuskan secara abstrak dalam sebuah kitab karena realitanya tidaklah demikian. Jangankan peranan yuridis materiil, peranan yuridis formal pun terkadang . terabaikan. Berbagai kasus yang telah mendapat putusan bukannya melindungi dan mensejahterakan masyarakat, justru sebaliknya masyarakat justru kehilangan dan kemudian terjadi proses pemiskinan adalah cerminan terabaikannya peranan-peranan yang ideal itu.

Dengan memperhatikan kondisi pengadilan yang semakin terpinggirkan dan semakin jauh dari peranannya, maka adalah menjadi alasan dan semakin memperbesar keinginan untuk melakukan revitalisasi pengadilan dengan sasaran peningkatan kesadaran peran dan tanggung jawab serta moralitas komponen pengadilan khususnya hakim.

Kesadaran terhadap peranan pengadilan hendaknya menjadi perhatian, oleh karena itu, sikap dan tindakan pengadilan yarig hanya berfokus pada tindakan menerapkan hukum

${ }^{13} \mathrm{Ibid}$. 
formal perlu kiranya ditingkatkan, sebab peranan yang demikian itu hanyalah salah satu peranan kecil dari sekian peranan-peranan yang ada dan harus dimilikinya. Sudah saatnya pengadilan hendaknya tidak hanya bertugas menerapkan hukum pada kasus-kasus konkrit, melainkan harus pula menyadari bahwa peranannya jauh lebih besar karena harus menembus peranan yang bersifat yuridis material yang syarat akan kedamaian, keadilan, keamanan dan kesejahteraan masyarakat.

Upaya untuk menggalaḱan peningkatan kesadaran akan peranan baik yang bersifat yuridis formal maupun peranan yang bersifat yuridis materiil, akan lebih mudah tercapai bila diikuti dengan peningkatan tanggung jawab. Ruang lingkup tanggung jawab (akuntabilitas) pengadilan meliputi dan berdimensi luas, tanggung jawab ini meliputi tanggung jawab kepada hukum, kepada diri sendiri, kepada rakyat dan kepada Tuhan Yang Maha Esa. ${ }^{14}$ Pengadilan hendaknya menyadari tanggung jawab ini, sehingga bila mana ia berbuat dan bertindak tidaklah sekedar menerima, memeriksa kemudian menjatuhkan palu kepada mereka yang bersengketa atau yang dihadapkan kepadanya melainkan juga bahwa dari keseluruhan perbuatannya itu senantiasa diarahkan guna menetapkan dan mewujudkan hukum yang berintikan keadilan berdasarkan Ketuhanan Yang Maha Esa.

Upaya untuk mengembalikan dan meningkatkan kesadaran baik kesadaran akan peran dan kesadaran akan tanggung jawab sangat diperlukan sebuah gerakan moral, karena sumber timbulnya kesadaran itu tersangkut paut erat dengan faktor moralitas. Timbulnya kesadaran akan adanya tanggung jawab kepada Tuhan sangat tergantung kepada baik buruknya moral (akhlak) yang dimilikinya. Oleh karena itu, agenda revitalisasi pengadilan harus pula menyentuh pada masalah moral. Mengingat moral para penggerak pengadilan (khususnya dalam hal ini hakim) dinilai berada pada titik terendah, dan inilah salah satu faktor yang mempengaruhi rendahnya kemandirian pengadilan sehingga sulit menjalankan keseluruhan peran-peran yang dimilikinya.

Dengan melalui strategi revitalisasi pengadilan diharapkan akan tumbuh tingkat kesadaran terhadap peran baik peran yang bersifat yuridis formal maupun yang bersifat yuridis materiil, akan tumbuh tanggung jawab baik tanggung jawab kepada hukum, masyarakat dan terutama tanggung jawab kepada Tuhan, dan diharapkan pula akan mendapatkan komponen-komponen hakim yang bermoral mahmudah dan berintegritas tinggi. Jika harapan ini terwujud dengan sendirinya kemandirian pengadilan pun akan dapat terwujud pula.

\section{Simpulan}

Strategi dalam membangun kemandirian pengadilan adalah satu langkah yang dipilih untuk mengembalikan posisi pengadilan sebagai lembaga yang terhormat sejajar dengan lembaga-lembaga negara lainnya dan menempatkannya sebagai lembaga independen bukan sebagai lembaga dependen. Strategi yang dilakukan tidak hanya berdasarkan pada bagian-bagian tertentu dari pengadilan melainkan menjangkau kepada keseluruhan komponen-komponen yang

${ }^{11}$ C.S.T. Kansil, op.cit, him. 6 
berhubungan dan berpengaruh terhadap kemandirian pengadilan, yakni komponen struktural, peraturan hukum dan komponen manusianya.

Atas dasar komponen-komponen yang berpengaruh itu maka strategi dalam membangun kembali kemandirian pengadilan, antara lain dapat dilakukan dengan restrukturisasi pengadilan. Restrukturisasi pengadilan lebih di arahkan kepada persoalanpersoalan struktural berupa kedudukan organisasi, rekruitmen, jaminan profesi, kesejahteraan para hakim dan kewenangan khsusnya mengenai hak uji materiil.

Strategi lainnya yang dapat dilakukan dalam membangun kemandirian pengadilan adalah reformasi terhadap perundangundangan. Reformasi ini dilakukan terhadap materi undang-undang yang tidak mendukung mekanisme kerja sebagai lembaga terpadu dan mandiri. Untuk mendukung ke arah itu maka reformasi ini dilakukan tidak saja pada dataran undang-undang organik melainkan juga menjangkau pada dataran konstitusi (UUD)

Strategi restrukturisasi dan reformasi terhadap perundang-undangan tidak akan banyak artinya jika tidak diikuti dengan revitalisasi pengadilan sebab, berbagai perilaku pengadilan yang tidak menyenangkan mengakibatkan melemahnya kemandirian pengadilan itu sendiri. Oleh karena itu untuk mendukung kedua strategi tersebut, strategi berupa revitalisasi pengadilan harus pula dilakukan dengan sasaran tumbuhnya kembali kesadaran akan peran dan tanggung jawab pengadilan serta terjadinya perbaikan moralitas khususnya para hakim.

\section{Daftar Pustaka}

Arief, Barda Nawawi, "Sistem Peradilan Pidana Terpadu dalam Kaitannya dengan Pembaharuan Kejaksaan," disajikan pada forum Dengar Pendapat Publik, Pembaruan Kejaksaan, di Jakarta: 2425 Juni 2003,

Basuki, Kuntoro dan Retnosupartinah, Kumpulan Undang-undang dan Peraturan-Peraturan Pemerintah Yang Berhubungan dengan Masalah Peradilan, Yogyakarta: Sekși Peradilan Fakultas Hukum UGM, 1980

Departement of Intemational Economic and Social Affairs, Sevent United Nations Congress On The Prevention of Crime And The Treatment Of Offenders Milan, 26 August-6 September 1985, New York: United Nations Publications, 1986

Friedman, Lawrence M. Law And Society An Introduction, United States of America: Prentice-Hall, inc,. Rnglewood Cliffs, N.J. 07632, 1977.

Friedman, Lawrence M. The Legal System, $A$ Social Science Perspective, New York: Russell Sage Foundtion, 1975.

Mahendra, Yusril Ihza, "Adakah Kemerdekaan Kekuasaan Kehakiman", Makalah dalam seminar Kekuasaan Kehakiman dan Sistem Peradilan Di Indonesia pada Fak. Huk. UNDIP, Semarang 1996.

Mertokusumo, Sudikno, "Revitalisasi dan Fungsionalisasi Lembaga Peradilan ", Makalah pada Diskusi Usulan Rancangan GBHN'98 Fakultas Hukum UII Yogyakarta, 15 Juli 1987. 
Muhammad, Rusli, "Reformasi Kekuasaan Kehakiman (Studi Sinkronisasi UUD 1945 dan UU. No. 14 Tabun 1970)," dalam Jumal Hukum \& Keadilan Vol. 1 Number 1 Tahun 1998.

Muhammad, Rusli, "Urgensị dan Upaya Revitalisasi Lembaga Peradilan," dalam Jumal Hukum No. 2 Vol 1 Tahun 1997.
Rahardjo, Satjipto, Hukum dan Perubahan Sosial, Bandung: Penerbit Alumni, 1983.

Shetreet, Shimon dan Jules Deschenes, ed. Judicial Independence The Conttemporary Debate, Netherlands, Martinus Nijhoff Publishers,1985. 